\title{
Effect of Dietary REE Supplementation on Intestinal Microbial Count and Ileal Digestibility in Post peak Layer Chicken
}

\author{
D. Reka ${ }^{1 *}$, V. Thavasiappan ${ }^{2}$, P. Selvaraj ${ }^{1}$, A. Arivuchelvan ${ }^{3}$, \\ P. Visha ${ }^{4}$ and Manju G. Preedaa ${ }^{1}$ \\ ${ }^{I}$ Department of Veterinary Physiology, Veterinary College and Research Institute, \\ Namakkal, Tamilnadu-India \\ ${ }^{2}$ Sheep Breading Research Station, Sandynallah, Tamilnadu-India \\ ${ }^{3}$ Department of Veterinary Pharmacology and Toxicology, Veterinary College and Research \\ Institute, Tirunelveli, Tamilnadu-India \\ ${ }^{4}$ Department of Veterinary Physiology and Biochemistry, Veterinary College and Research \\ Institute, Orathanadu, Tamilnadu-India \\ *Corresponding author
}

\section{A B S T R A C T}

\begin{tabular}{|l|}
\hline Ke y w o r d s \\
Rare earth elements, \\
Microbial count, \\
Ileal digestibility, \\
Laying hens
\end{tabular}

A biological study was conducted to determine the effects of dietary supplementation of different levels of rare earth elements (lanthanum and cerium) on intestinal microbial count, ileal digestibility in post peak laying hens. A total of 96 White Leghorn laying hens of 52 weeks of age were used in 8 week feeding trial. Birds were randomly allotted to three dietary treatments each with four replicates and 8 hens per replicate. Treatments consist of basal diet supplemented with $0,250 \mathrm{mg}$ (lanthanum $100 \mathrm{mg}$ and cerium $150 \mathrm{mg}$ ) and $500 \mathrm{mg} / \mathrm{kg}$ (lanthanum 200mg and cerium $300 \mathrm{mg}$ ) of rare earth elements. At the end of $60^{\text {th }}$ week, six birds per treatment were randomly selected and sacrificed. Intestinal contents were collected in sterile vials for intestinal microbial count, ileal digestibility and stored in airtight containers at $-4^{\circ} \mathrm{C}$. The results of this study showed that supplementation of rare earth elements (lanthanum and cerium) did not change the mean intestinal microbial count $(\log 10 \mathrm{cfu} / \mathrm{g})$ among the treatment groups. The ileal nutrient digestibility (\%) of crude protein, crude fibre and ether extract of post peak layers showed 1-2 per cent improvement among the treatment groups over the control.

\section{Introduction}

Rare earth elements are a set of seventeen chemical elements in the periodic table, specifically the fifteen lanthanides plus scandium and yttrium. REE can improve digestibility and utilization of nutrients in the diet (Li et al., 1992) which may be achieved through influencing the development of selected bacterial groups in the intestinal tract, or through stimulating activities of the hormones such as growth hormone and 
triiodothyronine (Redling, 2006). Because there is a special relationship between REE and calcium in both animal and plant cells, it is also suggested that REE may affect activities of the hormones or enzymes by inhibiting or replacing calcium (Takada et al., 1999). Rare earth elements have been shown to promote the animal growth by influencing the growth of bacterial species within the gastrointestinal tract selectively, by inhibiting undesired bacteria (Rambeck and Wehr, 2005). Hence, Rare earth elements maintain the micro-flora of the intestinal tract, which is involved in digestion processes, and prevent the disease onsets (Redling, 2006).

Rare earth elements cause bacterial flocculation by altering the structure and surface charge of bacterial membranes (Bentz et al., 1988). By this same manner, rare earth elements promoted cell aggregation and membrane fusion (Cassone and Garaci, 1974). In general, Gram negative bacteria usually have a peptidoglycan layer beneath the lipopolysaccharide which makes them less sensitive to lysozyme. Peng et al., (2004) showed that $\mathrm{La}^{3+}$ caused damage to the Gram negative bacteria by changing the structure of outer cell membrane.

Muroma, (1958) reported that the presence of lanthanum increased the susceptibility of bacteria to lysozymes. REE reduce the bacterial metabolism by inhibiting the respiration process (Brooks, 1921). Wenhua et al., (2003) reported that lower concentrations $(0.5-30 \mu \mathrm{g} / \mathrm{kg}), \mathrm{La}^{3+}$ could inhibit the absorption of external DNA by $E$. coli, thereby effectively decreasing its transformation effectively. Ou et al., (2000) suggested that rare earth elements additives lowered the $\mathrm{pH}$ value in the digestive tract of piglets, thus suppressed the growth of pathogenic bacteria by its acid character. Cerium inhibits the growth of several bacteria including E. coli, Bacillus pyocyaneus,
Staphylococcus aureus, Leuconostoc and Streptococcus faecalis, when applied at concentrations ranging from $10^{-3} \mathrm{~mol} / 1$ to $10^{-2} \mathrm{~mol} / \mathrm{l}$ (Zhang et al., 2000).

Rare earth elements supplementation in feed improved the utilization of dietary nutrients such as total energy, crude protein and crude fat in chicken (Xie and Wang, 1998). Supplementation of rare earth elements at the level of 200,400 or $600 \mathrm{mg} / \mathrm{kg}$ diet in weaning pigs showed significantly improved apparent digestibility of energy and protein, digestibility of total amino acids and total essential and non-essential amino acids in 400 and $600 \mathrm{mg} / \mathrm{kg}$ of REE supplemented groups compared to control (Hu et al., 1999).

Therefore the aim of this study was to investigate the effects of dietary rare earth element on intestinal microbial count and ileal digestibility in post peak laying hens.

\section{Materials and Methods}

\section{Experimental birds}

A total of 96 White Leghorn layers of 52 weeks of age were randomly assigned to three dietary treatment groups for 8-weeks feeding trial and the experiment was conducted at the Poultry Farm Complex, Department of Poultry Science, Veterinary College and Research Institute, Namakkal, Tamil Nadu. Laying hens were randomly assigned to three treatments with four replicates per treatment, and there were 8 hens in each replicate. The layers were reared in cages in gable roofed open sided, elevated platform house. All the birds were provided with a uniform cage floor, feeder and water space and were reared under standard management conditions throughout the experimental period. The experimental layer diets (Table 1) were formulated according to the breeder's specification (Venkateshwara Hatcheries 
Private Limited). Basal diet supplemented with 0,250 (La 100mg, Ce 150mg) and $500 \mathrm{mg} / \mathrm{kg}$ (La 200, Ce $300 \mathrm{mg}$ ) of REE.

\section{Collection of intestinal contents}

At the end of $60^{\text {th }}$ week, six birds per treatment were randomly selected and sacrificed. Intestinal contents were collected in sterile vials for microbial count. Samples for ileal digestibility studies were taken from the ileal region lying $18 \mathrm{~cm}$ below the Meckels diverticulum and stored in airtight containers at $-4^{\circ} \mathrm{C}$.

\section{Microbial count}

Immediately after slaughter, the intestinal content was transferred to sterile sample container and transferred to the laboratory. One gram of intestinal content from each experimental group was pooled, thoroughly mixed in the laboratory and made into duplicate samples. A serial dilution up to $10^{-8}$ was prepared. Each sample was diluted with $9 \mathrm{ml}$ of sterile physiological saline solution and it was thoroughly mixed. From each dilution $100 \mu \mathrm{l}$ of aliquot was spread on the appropriate selective agar plates and incubated at $37^{\circ} \mathrm{C}$ for $24 \mathrm{~h}$. Total plate count agar, MacConkey agar, MRS agar were used as the medium for estimation of total bacterial count, Escherichia coli count and Lactobacillus respectively by spread plate method. After incubation, the colonies were counted and expressed as the numbers of colony forming (cfu) per gram of ingesta content as per the method of Quinn et al., (1992).

\section{Ileal digestibility}

The ileal digestibility was studied using titanium dioxide $\left(\mathrm{TiO}_{2}\right)$ as marker added at the rate of $10 \mathrm{~g}$ per $\mathrm{kg}$ of feed. Six birds from each group were fed with $\mathrm{TiO}_{2}$ containing diets for five days to study the ileal digestibility. Birds were slaughtered on day six and ileal contents were milked out immediately into a container. These samples were pooled across treatments. The ileal digesta immediately after collection were transferred into the oven and dried at $80^{\circ} \mathrm{C}$ for $24 \mathrm{~h}$. The dried ileal digesta samples were stored in airtight containers at $-4^{\circ} \mathrm{C}$ and were analyzed for crude protein, crude fiber and ether extract. The $\mathrm{TiO}_{2}$ content of the feed and ileal digesta were estimated according to the method of Myers et al., (2004).

\section{Statistical analysis}

The data collected were analysed using SPSS ${ }^{\circledR} 20.0$ software package. Post hoc analysis was done by Duncan's multiple descriptive significant difference. All the statistical procedures were performed based upon Snedecor and Cochran (1994).

\section{Results and Discussion}

The influence of Rare earth elements at different levels on intestinal microbial count and ileal digestability in post peak layers are presented in tables 2 and 3 .

The mean intestinal microbial count $(\log 10$ $\mathrm{cfu} / \mathrm{g}$ ) of post peak layer did not vary significantly among the treatment groups.

The results of the present study concurred with that of Cai et al., (2015) and Cai et al., (2016), who reported no change in lactobacillus and E. coli count when rare earth element enriched yeast (0.05 to $1.0 \%)$ fed in birds compared to control. Similarly, rare earth elements did not affect the composition of faecal bacterial populations in pigs, which was investigated in biomolecular studies using PCR-DGGE methods (Polymerase Chain Reaction Amplification (PCR) - Denaturing Gradient Gel 
Electrophoresis (DGGE)) (Kraatz et al., 2004). The ileal nutrient digestibility (\%) of crude protein, crude fibre and ether extract of post peak layer showed 1-2 per cent improvement among the treatment groups. These results are in concurrence with the finding of Xie and Wang, (1998) reported that layer diets influenced positively the nutrient digestibility of crude protein, crude fibre and crude fat by supplementation of organic rare earth elements compared to control diet. Similarly, improved apparent digestibility in piglets by addition of Rare earth elements mixture (Hu et al., 1999), improved dry matter digestibility in broilers chicken at different levels of dietary rare earth element enriched yeast (Cai et al., 2015) in treatment groups compared to control. However, Cai et al., (2016) reported no changes in dry matter, gross energy and increased nitrogen digestibility when rare earth element enriched yeast $(0.05$ to $1.0 \%)$ fed in birds compared to control.

Table.1 Ingredients and nutrient composition of experimental layer diet (DM \%)

\begin{tabular}{|l|c|}
\hline \multicolumn{1}{|c|}{ Ingredients } & Kg/100 kg diet \\
\hline Maize & 50.5 \\
\hline DORB & 13.5 \\
\hline SOYA & 6.0 \\
\hline Calcite/LSP & 17.5 \\
\hline Grit & 5.5 \\
\hline Di calcium phosphate & 5.0 \\
\hline Methionine & 1.5 \\
\hline Lysine & 0.164 \\
\hline NSP Enzyme & 0.117 \\
\hline Salt & 0.05 \\
\hline Nutrient compositions $\mathbf{( \% )}$ & 0.137 \\
\hline Crude protein & 16.67 \\
\hline Crude fibre & 6.4 \\
\hline Calcium & 4.0 \\
\hline Ether extract & 3.0 \\
\hline Available phosphorus* & 0.41 \\
\hline Lysine* & 0.89 \\
\hline Methionine* & 0.45 \\
\hline Metabolizable Energy* (kcal/kg) & 2550 \\
\hline
\end{tabular}

* Calculated values

Additives and supplements (per $100 \mathrm{~kg}$ ): Vitamin premix $\left({ }^{1}\right.$ Hyblend) - $10 \mathrm{~g}$, trace mineral $\left({ }^{2} \mathrm{Ultra} \mathrm{TM}\right)$ - $100 \mathrm{~g}$, toxin binder - $25 \mathrm{~g}$, Vitamin B-complex ( ${ }^{3}$ Meriplex) - $10 \mathrm{~g}$, liver stimulant (hepatocare) - $25 \mathrm{~g}$, choline chloride (60 $\%)$ - $50 \mathrm{~g}$, oxytetracycline $(10 \%)-50 \mathrm{~g}$

${ }^{1}$ Hyblend - nutritional value per gram- vitamin A - $82500 \mathrm{IU}$, vitamin B2 - $50 \mathrm{mg}$, vitamin D3 - 12000 IU, menaphthone sodium bisulphate and vitamin K (stabilized) - $10 \mathrm{mg}$.

${ }^{2}$ Ultra TM - Each 5kg contains manganese - 270 g, zinc - 260 g, iron - 100 g, iodine - 10 g, copper - 10 g, cobalt - 5 $\mathrm{g}$, selenium - $1.5 \mathrm{~g}$

${ }^{3}$ Meriplex - each gram contains vitamin $\mathrm{B}_{1}-8 \mathrm{mg}$, vitamin $\mathrm{B}_{6}-16 \mathrm{mg}$, vitamin $\mathrm{B}_{12}-80 \mathrm{mcg}$, vitamin $\mathrm{E}_{50}-80 \mathrm{mg}$, niacin - $120 \mathrm{mg}$, folic acid - $8 \mathrm{mg}$, calcium D pantothenate - $80 \mathrm{mg}$, calcium - $86 \mathrm{mg}$. 
Table.2 Mean $( \pm$ SE) Intestinal microbial count $(\log 10 \mathrm{cfu} / \mathrm{g})$ of White Leghorn layers fed with different levels of REE during 60 weeks of age

\begin{tabular}{|c|c|c|c|}
\hline Treatment & $\begin{array}{l}\text { Total Microbial count } \\
(\log 10 \mathrm{cfu} / \mathrm{g})\end{array}$ & $\begin{array}{l}\text { E.coli count } \\
(\log 10 \mathrm{cfu} / \mathrm{g})\end{array}$ & $\begin{array}{c}\text { Lactobacillus spp } \\
\text { count } \\
(\log 10 \mathrm{cfu} / \mathrm{g})\end{array}$ \\
\hline $\begin{array}{c}\text { T1 } \\
\text { Control }\end{array}$ & $9.12 \pm 0.03$ & $5.69 \pm 0.27$ & $5.19 \pm 0.31$ \\
\hline $\begin{array}{c}\text { T2 } \\
250 \mathrm{mg} \\
\text { (La } 100 \mathrm{mg}+\mathrm{Ce} \\
150 \mathrm{mg} \text { ) }\end{array}$ & $8.89 \pm 0.3$ & $5.36 \pm 0.18$ & $5.28 \pm 0.36$ \\
\hline $\begin{array}{c}\text { T3 } \\
500 \mathrm{mg} \\
\text { (La } 200 \mathrm{mg}+\mathrm{Ce} \\
300 \mathrm{mg} \text { ) }\end{array}$ & $9.40 \pm 0.16$ & $5.66 \pm 0.18$ & $5.33 \pm 0.27$ \\
\hline
\end{tabular}

Table.3 Effect on nutrient digestibility (\%) in White Leghorn layers fed different levels of REE in 60th week of age

\begin{tabular}{|c|c|c|c|}
\hline \multirow[t]{2}{*}{ Treatment } & \multicolumn{3}{|c|}{ Digestibility coefficient (\%) } \\
\hline & Crude protein & Crude fibre & Ether extract \\
\hline $\begin{array}{c}\text { T1 } \\
\text { Control }\end{array}$ & 77.87 & 19.53 & 69.46 \\
\hline $\begin{array}{c}\text { T2 } \\
250 \mathrm{mg} \\
(\text { La } 100 \mathrm{mg}+ \\
\text { Ce } 150 \mathrm{mg})\end{array}$ & 78.35 & 20.05 & 71.31 \\
\hline $\begin{array}{c}\text { T3 } \\
500 \mathrm{mg} \\
\text { (La } 200 \mathrm{mg}+\mathrm{Ce} \\
300 \mathrm{mg} \text { ) }\end{array}$ & 79.30 & 20.45 & 71.14 \\
\hline
\end{tabular}

Each value is a mean of two observations

In conclusion the results of the experiment revealed that supplementation of rare earth elements (lanthanum and cerium) did not change the mean intestinal microbial count $(\log 10 \mathrm{cfu} / \mathrm{g})$ among the treatment groups. The ileal nutrient digestibility (\%) of crude protein, crude fibre and ether extract of post peak layers showed 1-2 per cent improvement among the treatment groups over the control. Growth performance enhancing effects due to dietary supplementation of rare earth elements at low concentrations are described for nearly all categories of farming animals, including beef cattle, sheep, pigs, rabbits, ducks, chickens, shrimps and fish (Redling, 2006). Probiotics, prebiotics, organic acids and enzymes are already known as replacement for antibiotic feed additives but rare earth elements might be the new generation of growth promoters. 


\section{Acknowledgement}

The authors wish to thank the Dean, Veterinary College and Research Institute, Namakkal and Tamil Nadu Veterinary and Animal Sciences University for providing necessary funds and research facilities to carry out the study.

\section{References}

Bentz, J., Alford, D., Cohen, J. and Duzgunes, N. 1988. $\mathrm{La}^{3+}$-induced fusion of phosphatidylserine liposomes, close approach, intermembrane intermediates, and the electrostatic surface potential. Bio. J., 53: 593-607.

Brooks, M. M. 1921. Comparative studies on respiration: XIV. Antagonistic action of lanthanum as related to respiration. $\mathrm{J}$. Gen. Physiol., 3: 337-342.

Cai, L., Nyachoti, C.M., Hancock, J.D., Lee, J.Y., Kim, Y.H., Lee, D.H. and Kim, I.H. 2016. Rare earth element-enriched yeast improved egg production and egg quality in laying hens in the late period of peak egg production. J. Anim. Physiol. Anim. Nutr., 100: 492-498.

Cai, L., Park, Y.S., Seong, S.I., Yoo, S.W. and Kim, I.H. 2015. Effects of rare earth elements-enriched yeast on growth performance, nutrient digestibility, meat quality, relative organ weight, and excreta microflora in broiler chickens. Live. Sci., 172: 43-49.

Cassone, A., and Garaci, E. 1974. Lanthanum staining on the intermediate region of the cell wall in E. coli. Experientia., 30: $1230-1232$.

Hu, Z., Wang, J., Yang, Y. and Ma, Y. 1999. Effect of REE on the nutrients digestibility for growing pigs. Feed World, 11: 29-31.

Kraatz, M., Taras, D., Manner, K. and Simon, O. 2006. Weaning pig performance and faecal microbiota with and without in feed addition of rare earth elements. J. Anim. Physio. Anim. Nut., 90: 361368.

Li, D., She, W., Gong, L., Yang, W. and Yang, S. 1992. Effects of rare earth elements on the growth and nitrogen balance of growing pigs. Feed BoLan., 4: $3-4$.

Muroma, A. 1958. Studies on the bactericidal action of salts of certain rare earth metals. Annales Medicinae Experimentalis et Biologiae Fenniae, 36(6):1-54.

Myers, W. D., Ludden, P. A., Nayigihugu, V. and Hess, B.W. 2004. Technical Note: A procedure for the preparation and quantitative analysis of samples for titanium dioxide. J. Anim. Sci., 82: 179183.

Ou, X., Guo, Z. and Wang, J. 2000. The effects of rare earth element additive in feed on piglets. Live. Poult. Indu., 4: 21-22.

Peng, L., Yi, L., Zhexue, L., Juncheng, Z., Jiaxin, D., Daiwen, P., Ping, S. and Songsheng, W. 2004. Study on biological effect of La3+ on Escherichia coli by atomic force microscopy. J. Inorg. Biochem., 98: 68 - 72.

Quinn, P. J., Carter, M. E., Markey, B. K. and Carter, G. R. 1992. Clinical Veterinary Microbiology. Mosby-year book Europe Limited Lynton House, 7-12 Tavistock square, London, 61-65.

Rambeck, W. A. and Wehr, U. 2005. Use of rare earth elements as feed additives in pig production. Pig News and Inform., 26(2).

Redling, K. 2006. Rare earth elements in agriculture with emphasis on animal husbandry. Diss. the Ludwig Maximilian University, Munich.

Snedecor, G. M. and Cochran, W. C. 1994. Statistical Methods. $9^{\text {th }}$ Edn. Oxford and IBM Publishing company, Mumbai, India. 
Takada, J., Sumino, T., Nishimura, K., Tanaka, Y., Kuwamoto, K. and Akaboshi, M. 1999. Unusual interrelationship between rare earth element and calcium contents in fern leaves. J. Radioant. Nucl. Chem., 239: $609-612$.

Wenhua, L., Ruming, Z., Zhixiong, X., Xiangdong, C. and Ping. S. 2003. Effect of La3+ on growth, transformation and gene expression of Escherichia coli. Biological Trace Element Research, 94:
$167-177$.

Xie, J. and Wang, Z. 1998. The effect of organic rare earth compounds on production performance of chicken. Page 74 in 2nd International Symposium on Trace Elements and Food Chain, Wuhan, China.

Zhang, H., Feng, J., Zhu, W. F., Liu, C. and $\mathrm{Gu}$, J. 2000. Bacteriostatic effect of cerium-humic acid complex: An experimental study. Biological Trace Element Research, 73(1): 29-36.

\section{How to cite this article:}

Reka, D., V. Thavasiappan, P. Selvaraj, A. Arivuchelvan, P. Visha and Manju G. Preedaa. 2019. Effect of Dietary REE Supplementation on Intestinal Microbial Count and Ileal Digestibility in Post peak Layer Chicken. Int.J.Curr.Microbiol.App.Sci. 8(04): 1597-1603. doi: https://doi.org/10.20546/ijcmas.2019.804.185 